\title{
Pengetahuan Nutrition Facts dan Pemilihan Makanan Kemasan Mahasiswa Obesitas antara Metode Edukasi Personal dan Ceramah
}

\section{Nutrition Facts's Knowledge and Food Packaging Choice of Obese Students between Personal Education Method and Lecture Method}

\author{
Ismi Ningtyas*1, Dian Handayani², Inggita Kusumastuty ${ }^{3}$
}

\begin{abstract}
ABSTRAK
Latar Belakang: Kejadian obesitas meningkat tanpa memandang usia. Obesitas dapat disebabkan karena kegemaran mengonsumsi snack/makanan kemasan dan jarang memperhatikan kandungan dalam label informasi nilai gizinya. Metode edukasi personal merupakan pemberian edukasi yang dilakukan pada perorangan, sedangkan metode ceramah dilakukan pada sasaran kelompok dan masing-masing metode memiliki kelebihan dan kekurangan.

Tujuan: Mengetahui perbedaan tingkat pengetahuan tentang label informasi nilai gizi dan pemilihan makanan kemasan antara metode edukasi gizi personal dan metode ceramah pada mahasiswa obesitas.

Metode: Desain penelitian ini adalah quasi eksperimen dengan pre-test post-test group design. Teknik sampling menggunakan purposive sampling dengan jumlah sampel sebanyak 44 orang mahasiswa obesitas di Universitas Brawijaya. Variabel yang diteliti adalah tingkat pengetahuan terkait label informasi nilai gizi dan pemilihan makanan kemasan melalui kuesioner pada kelompok metode edukasi personal dan ceramah menggunakan pengukuran pre-test-post-test.

Hasil: Terdapat perbedaan yang signifikan antara hasil pre-test dan post-test tingkat pengetahuan pada kedua kelompok $(p=0,000)$ dan pemilihan makanan kemasan pada kelompok edukasi personal $(p=0,000)$. Namun, tidak terdapat perbedaan pemilihan makanan kemasan yang signifikan antara hasil pre-test dan post-test pada kelompok ceramah $(p=0,317)$. Terdapat perbedaan yang signifikan pada hasil post-test tingkat pengetahuan $(p=0,038)$ dan pemilihan makanan kemasan $(p=0,000)$ antara kedua kelompok setelah diberi edukasi gizi.

Kesimpulan: Berdasarkan hasil penelitian dapat disimpulkan bahwa dengan sasaran mahasiswa obesitas, metode edukasi personal dan ceramah dapat meningkatkan pengetahuan terkait label informasi nilai gizi dan pemilihan makanan kemasan walaupun edukasi personal memberikan efek yang lebih besar.
\end{abstract}

Kata kunci: edukasi personal, ceramah, tingkat pengetahuan, pemilihan makanan kemasan, label informasi nilai gizi

\section{ABSTRACT}

Background: The incidence of obesity increases regardless of age. It may happen because these students like to consume snacks/ packaged foods and rarely pay attention to the contents of Nutrition Facts label. Personal education method is a method of education conducted on individuals, while lecture method conducted in groups, each methods has their advantages and disadvantages.

Objectives: Knowing the difference of knowledge level about Nutrition Facts label and packaged food choice between personal education method and lecture method on obese students. 
Methods: This study was a quasy experiment with pre-test and post-test group design. Forty four samples from undergraduate student of Brawijaya University were recruited by using purposive sampling. The variables of this study were knowledge level about Nutrition Facts label and food packaging choice through questionnaires in both groups based on pre-test and post-test measurements.

Results: There was a significant difference of knowledge level based on pre-test and post-test result in both of the group $(p=0.000)$ and packaged food choice in personal education group $(p=0.000)$. Nevertheless, there was no significant difference in packaged food choice based on pre-test and posttest of lecture group ( $p=0.317)$. There was a significant difference of knowledge level $(p=0.038)$ and packaged food choice $(p=0.000)$ based on post-test result in both of the group after nutritional education was given.

Conclusions: Based on study finding, it was concluded that in college student with obesity, personal education and lecture method improve knowledge level about Nutrition Facts label and packaged food choice albeit personal education method gives a bigger effect.

Keywords: personal education, lecture, knowledge level, packaged food choice, nutrition facts label

\footnotetext{
*Koresponden:

ismi.ningtyas@gmail.com

1,2,3 Jurusan Gizi, Fakultas Kedokteran, Universitas Brawijaya

Malang, Jawa Timur, Indonesia
}

\section{PENDAHULUAN}

Makanan kemasan wajib mencantumkan informasi yang jelas terkait kandungan gizi dan keterangan lain berupa label pangan untuk memudahkan konsumen dalam pemilihan pangan ${ }^{1}$. Penggunaan label pangan terutama label informasi nilai gizi ini juga didukung dalam 10 Pesan Gizi Seimbang ${ }^{2}$. Namun, hanya $6,7 \%$ masyarakat Indonesia yang memperhatikan label kemasan pangan $^{3}$, dan label informasi nilai gizi paling jarang diperhatikan oleh konsumen ${ }^{4}$.

Hasil penelitian pada konsumen Pasar Swalayan Setiabudi Semarang dan pada pasien Penyakit Jantung Koroner dan hipertensi menyebutkan bahwa tingkat pengetahuan terkait label kemasan makanan seperti cara yang benar dalam membaca informasi nilai gizi sangat berperan penting dalam tindakan pemilihan makanan kemasan seseorang, terutama bagi orang dengan status gizi obesitas yang membutuhkan pengendalian intake energi ${ }^{5,6}$.

Obesitas saat ini menjadi masalah kesehatan yang terus meningkat di berbagai kalangan usia ${ }^{7}$. Berdasarkan data Dinas Kesehatan Kota Malang tahun 2015, prevalensi obesitas di Kota Malang untuk laki-laki dan perempuan berusia $\geq 15$ tahun berturut-turut mencapai $35,49 \%$ dan $43,36 \%^{8}$. Faktor penyebab utama dari obesitas ini berasal dari lingkungan seperti perilaku makan, pola makan, dan aktivitas fisik ${ }^{9}$. Contoh dalam perilaku dan pola makan yaitu pemilihan makanan kemasan yang kurang baik, lebih memilih junk food dan minuman ringan/softdrink, terbiasa konsumsi jajan dan mengemil snack terutama golongan kripik dan makanan instan ${ }^{10}$.

Penerapan pembacaan label kemasan merupakan salah satu upaya preventif dan promotif dalam mengontrol asupan energi terutama pada orang dengan status gizi obesitas $^{8}$. Pada beberapa penelitian sebelumnya menyarankan bahwa diperlukan adanya peningkatan sosialisasi dan edukasi gizi dalam masyarakat terkait pentingnya penggunan label dalam memilih produk makanan kemasan terutama pada label informasi nilai gizi ${ }^{6}$. Edukasi gizi ini dapat dilakukan dengan berbagai metode, diantaranya dengan metode edukasi personal/perorangan/individual dan metode ceramah, dimana kedua metode ini adalah metode yang sering digunakan dan memiliki kelebihan dan kekurangan masing-masing jika diterapkan pada kalangan tertentu seperti 
pada mahasiswa, sehingga dapat mempengaruhi keefektifannya dalam menyampaikan informasi.

Metode edukasi personal merupakan pendekatan secara individual atau perorangan, dimana dengan metode ini antara klien dan petugas akan lebih intensif dalam melakukan kontak mata, dapat menggali permasalahan lebih mendalam, dan akhirnya klien akan lebih mudah dalam menerima dan mengubah perilakunya atas kesadaran sendiri ${ }^{11}$. Metode ceramah merupakan proses penyaluran informasi satu arah dari penyuluh kepada peserta atau sasaran penyuluhan, dimana metode ini cocok digunakan untuk sasaran dengan pendidikan tinggi maupun rendah dan mudah dalam perencaanaannya dan efisien waktu ${ }^{12}$.

Selama ini belum ada penelitian yang membandingkan edukasi gizi tentang label informasi nilai gizi antara metode edukasi personal dan metode ceramah pada mahasiswa dengan status gizi obesitas. Oleh karena itu, peneliti tertarik untuk mengetahui bagaimana efektifitas perubahan tingkat pengetahuan tentang label informasi nilai gizi dan pemilihan makanan kemasan pada mahasiswa obesitas yang mendapatkan edukasi gizi dengan metode edukasi personal dan metode ceramah. Diharapkan hasil penelitian ini dapat digunakan dalam menambah pengetahuan tentang label informasi nilai gizi dan metode yang efektif digunakan pada masyarakat dengan status gizi obesitas.

\section{METODE}

Penelitian ini menggunakan desain quasi eksperimen dengan pendekatan pre-test-posttest group design ${ }^{13}$. Penelitian dilakukan di Kota Malang, yaitu di Universitas Brawijaya. Variabel yang diteliti adalah tingkat pengetahuan terkait label informasi nilai gizi dan pemilihan makanan kemasan pada kelompok edukasi personal dan kelompok ceramah berdasarkan hasil pre-test dan posttest.

Data yang digunakan dalam penelitian ini merupakan data primer. Data karakteristik responden diambil melalui pengisian kuesioner identitas responden. Data untuk pengukuran antropometri (berat badan, tinggi badan, dan IMT) diperoleh melalui pengukuran langsung oleh enumerator terlatih. Data gambaran tingkat pengetahuan tentang label informasi nilai gizi dan gambaran pemilihan makanan kemasan diambil melalui kuesioner pre-test dan post-test. Kuesioner pre-test dan post-test yang digunakan merupakan modifikasi dari penelitian sebelumnya dan sudah teruji validitas dan reliabilitasnya ( $r$ hitung 0,520 $>0,361$ dan $r$ Alpha 0,822>0,361). Terdapat 2 macam kuesioner, yaitu kuesioner untuk mengukur tingkat pengetahuan terkait label informasi nilai gizi dan kuesioner untuk mengetahui gambaran pemilihan produk makanan kemasan yang tepat untuk orang obesitas melalui label informasi nilai gizi.

Kuesioner pre-test dan post-test tingkat pengetahuan terdiri dari 20 pertanyaan yang sama, 7 pertanyaan terkait gambaran umum label informasi nilai gizi (definisi, informasi yang wajib dicantumkan, zat gizi yang wajib dicantumkan, manfaat membaca label informasi nilai gizi), dan 13 pertanyaan terkait cara yang benar dalam membaca label informasi nilai gizi (terutama pada kandungan energi dan takaran saji untuk menghitung densitas energi, serta jumlah sajian per kemasan) dengan bobot skor 0 untuk jawaban salah dan 1 untuk jawaban benar.

Kuesioner pemilihan makanan kemasan berjumlah 5 pertanyaan dengan 10 pilihan produk makanan kemasan. Bobot skor 0 untuk pemilihan produk dan alasan pemilihan makanan kemasan yang salah dan 1 untuk pemilihan produk dan alasan pemilihan makanan kemasan yang benar. Tingkat pengetahuan dikategorikan menjadi kurang baik (jawaban benar $60 \%$ ), cukup baik (jawaban benar antara 60-80\%), dan baik (jawaban benar $>80 \%)^{14}$. Pemilihan makanan kemasan dikategorikan berdasarkan jenis produk makanan kemasan yang dipilih dan alasan pemilihan, yaitu kategori baik (memilih $>3$ produk benar dengan alasan tepat), cukup (memilih 3 produk yang benar dengan alasan tepat), dan kurang baik (memilih $<3$ produk yang benar dengan alasan tepat) ${ }^{15,16}$. Produk makanan kemasan yang benar adalah memiliki densitas energi rendah ( $<1 \mathrm{kkal} / \mathrm{gr})$ atau sedang $(1-2,24 \mathrm{kkal} / \mathrm{gr})^{15}$. 
Alasan pemilihan yang tepat adalah alasan selain kesukaan terhadap produk, yaitu karena memperhatikan densitas energi dan jumlah sajian per kemasan pada label yang dapat berpengaruh terhadap intake energi ${ }^{15,17}$. Populasi pada penelitian ini adalah mahasiswa dan mahasiswi obesitas di Kota Malang, dan sampel penelitian adalah mahasiswa dan mahasiswi S1 usia 18-25 tahun di Universitas Brawijaya dengan status gizi obesitas menurut WHO tahun $2004\left(\right.$ IMT $\left.\geq 25 \mathrm{~kg} / \mathrm{m}^{2}\right)$. Subjek penelitian ini diambil menggunakan teknik pusposive sampling sebanyak 44 orang responden dengan 22 orang responden pada masing-masing kelompok intervensi.

Instrumen yang digunakan meliputi informed consent, kuesioner data karakteristik responden, timbangan digital, microtoise, $\mathrm{H}-\mathrm{H}$ BIA merk Omron HBF 306 untuk mengukur IMT, lembar hasil rekap pengukuran antropometri, kuesioner pre-test dan post-test tingkat pengetahuan dan pemilihan makanan kemasan, serta media yang digunakan dalam proses edukasi gizi berupa booklet dan kemasan makanan sebagai food model.

Pada pertemuan pertama, dilakukan persetujuan informed consent, pengukuran antropometri, pengisian kuesioner karakteristik responden, dan dilakukan pre-test untuk tingkat pengetahuan dan pemilihan makanan kemasan dengan meminta responden mengisi kuesioner. Pemberian intervensi berupa edukasi gizi terkait gambaran umum label informasi nilai gizi dan cara membaca label informasi nilai gizi pada kelompok metode edukasi personal dan metode ceramah serta post-test dilakukan dalam rentang waktu 7 hari setelah pre-test. Hal ini untuk meminimalisir pengaruh dari luar sebelum dilakukannya intervensi dan agar responden tidak mengingat soal pre-test yang dapat berpengaruh pada respon dari intervensi dan sensitifitas ingatan responden ${ }^{18}$. Sedangkan post-test dilakukan sesaat setelah pemberian intervensi untuk menguji ingatan jangka pendek atau short term memory dari responden penelitian ${ }^{18}$. Pre-test dan post-test masing-masing dilakukan dalam waktu \pm 15 menit. Edukasi diberikan sebanyak satu kali dalam waktu \pm 30 menit dengan media booklet dan food model berupa kemasan makanan.
Proses pengolahan dan analisa data dilakukan menggunakan program komputer Microsoft Excel 2013 dan Statistical Program for Social Sciences (SPSS) versi 16.0. Seluruh data dari masing-masing variabel pada penelitian ini tidak terdistribusi normal. Sehingga untuk mengetahui perbedaan skor pengetahuan dan skor pemilihan makanan kemasan antara pre-test dan post-test pada masing-masing kelompok menggunakan Uji Wilcoxon dan menggunakan Uji Marginal Homogeneity untuk data kategorikalnya. Untuk mengetahui perbedaan skor pengetahuan dan skor pemilihan makanan kemasan sebelum dan sesudah edukasi gizi antara kedua kelompok menggunakan Uji Mann-Whitney dan menggunakan Uji Chi-Square untuk data kategorikalnya. Namun, hasil Uji Chi-Square yang dilakukan pada variabel post-test tingkat pengetahuan, pre-test dan post-test pemilihan makanan antara kedua kelompok tidak memenuhi syarat (nilai ekspektasi dibawah 5 berjumlah $33,3 \%>20 \%$ ) sehingga dilanjutkan menggunakan Uji Kolmogorov-Smirnov ( $2 \mathrm{x}$ $\mathrm{K})^{19}$. Analisis dilakukan dengan menggunakan tingkat kepercayaan $95 \% \quad(\alpha=0,05)$ untuk mengambil keputusan bahwa hipotesis dapat diterima atau tidak ${ }^{20}$.

Penelitian ini telah lolos etik dari Komisi Etik Penelitian Kesehatan Fakultas Kedokteran Universitas Brawijaya dengan No.294/EC/KEPK-S1-GZ/08/2017 dan telah mendapatkan infomed consent dari seluruh mahasiswa Universitas Brawijaya yang menjadi responden pada penelitian ini.

\section{HASIL DAN PEMBAHASAN}

\section{Karakteristik Responden Penelitian}

Hasil penelitian menunjukkan bahwa seluruh usia responden berada pada rentang 18-25 tahun. Rentang usia ini merupakan usia yang paling umum dimiliki seseorang dengan status mahasiswa S1 dan tergolong dalam usia dewasa muda. Seluruh responden pada penelitian ini sudah memasuki usia dewasa muda yang memilliki peningkatan kemampuan untuk menerima informasi terkait label informasi nilai gizi karena seiring dengan bertambahnya usia maka akan berpengaruh pada peningkatan pola pikir dan daya terima 
Tabel 1. Karakteristik Responden Kelompok Edukasi Personal dan Ceramah

\begin{tabular}{|c|c|c|c|c|c|c|c|}
\hline \multirow[t]{2}{*}{ Kategori } & \multicolumn{2}{|c|}{$\begin{array}{c}\text { Kelompok } \\
\text { Edukasi Personal } \\
\end{array}$} & \multicolumn{2}{|c|}{$\begin{array}{l}\text { Kelompok } \\
\text { Ceramah }\end{array}$} & \multicolumn{2}{|c|}{$\begin{array}{c}\text { Total } \\
\text { Responden }\end{array}$} & \multirow[t]{2}{*}{$p$-value } \\
\hline & $\mathbf{n}$ & $\%$ & $n$ & $\%$ & $\mathbf{n}$ & $\%$ & \\
\hline \multicolumn{8}{|l|}{ Usia } \\
\hline 18-25 tahun & 22 & 100 & 22 & 100 & 44 & 100 & 0,622 \\
\hline \multicolumn{8}{|l|}{ Jenis Kelamin } \\
\hline Laki-laki & 6 & 27,3 & 13 & 59,1 & 19 & 43,2 & 0,080 \\
\hline Perempuan & 16 & 72,7 & 9 & 40,9 & 25 & 56,8 & \\
\hline \multicolumn{8}{|l|}{ Kategori IMT* } \\
\hline Obesitas I & 10 & 45,5 & 14 & 63,6 & 24 & 54,5 & 0,475 \\
\hline Obesitas II & 12 & 54,5 & 8 & 36,4 & 20 & 45,5 & \\
\hline \multicolumn{8}{|c|}{$\begin{array}{l}\text { Pernah Memperoleh Informasi } \\
\text { terkait Label Informasi Nilai Gizi }\end{array}$} \\
\hline Tidak & 11 & 50 & 12 & 54,5 & 23 & 52,3 & 0,678 \\
\hline $\mathrm{Ya}$ & 11 & 50 & 10 & 45,5 & 21 & 47,7 & \\
\hline \multicolumn{8}{|l|}{ **Sumber Informasi } \\
\hline Media Cetak & 11 & 100 & 10 & 100 & 21 & 100 & \\
\hline Media Elektronik & 11 & 100 & 10 & 100 & 21 & 100 & \\
\hline Penyuluh/seminar & 4 & 18,2 & 4 & 40 & 8 & 38,1 & \\
\hline Tenaga Kesehatan & 1 & 9,1 & 5 & 50 & 6 & 28,6 & \\
\hline \multicolumn{8}{|c|}{ **Informasi yang didapatkan } \\
\hline Jelas & 4 & 36,4 & 4 & 40 & 8 & 38,1 & \\
\hline Kurang jelas & 7 & 63,6 & 6 & 60 & 13 & 61,9 & \\
\hline
\end{tabular}

terhadap informasi ${ }^{11}$. Rentang usia ini juga memiliki kesukaan terhadap makanan kemasan seperti keripik, snack ringan, dan jenis biskuit ${ }^{21}$. Sebagian besar responden belum pernah mendapatkan informasi mengenai cara membaca label informasi nilai gizi. Responden yang pernah mendapatkan informasi menyatakan bahwa informasi yang didapatkan sebagian besar masih kurang jelas.

Hal ini bisa terjadi karena kurangnya paparan informasi, hanya membaca informasi secara sekilas dan kesulitan mencari informasi yang benar ${ }^{22}$. Hail uji homogenitas menunjukan bahwa responden pada penelitian ini memiliki karakteristik yang homogen, sehingga akan memberikan hasil yang akurat untuk menilai hasil dari metode edukasi yang diberikan. Adapun data karakteristik responden dapat dilihat pada Tabel 1.

\section{Analisis Perbedaan Tingkat Pengetahuan dan Pemilihan Makanan Kemasan antara Sebelum dan Sesudah Pemberian Edukasi Gizi}

Berdasarkan hasil penelitian pada tabel
2 , pre-test tingkat pengetahuan yang dimiliki oleh sebagian besar responden pada kedua kelompok adalah kurang, dengan jumlah $63,6 \%$ pada kelompok edukasi personal dan $72,7 \%$ pada kelompok ceramah. Setelah diberi intervensi, sebesar $77.3 \%$ responden pada kelompok edukasi personal dan setengah dari responden pada kelompok ceramah memiliki hasil post-test tingkat pengetahuan yang baik. Jika dibandingkan dengan hasil pre-test tingkat pengetahuan, maka diperoleh peningkatan pengetahuan responden pada kedua kelompok menjadi kategori baik. Pada kelompok edukasi personal terdapat lebih banyak responden dengan tingkat pengetahuan baik dan tidak terdapat responden yang masih memiliki tingkat pengetahuan kurang baik jika dibandingkan dengan kelompok ceramah. Jika dilihat pada tabel 3, skor pengetahuan pada kedua kelompok mengalami peningkatan, namun peningkatan skor pada kelompok edukasi personal (32,4 poin) lebih tinggi daripada kelompok ceramah (20,6 poin). Adapun pre-test dan post-test skor dan tingkat 
pengetahuan responden dapat dilihat pada Tabel 2 dan 3.

Untuk pemilihan makanan kemasan, hasil penelitian menunjukkan bahwa pre-test dari seluruh responden pada masing-masing kelompok edukasi personal dan ceramah memiliki pemilihan makanan kemasan yang kurang baik. Setelah diberi intervensi, sebesar $59.1 \%$ responden pada kelompok edukasi personal memiliki hasil post-test pemilihan makanan kemasan yang baik, sedangkan sebesar 95,5\% responden pada kelompok ceramah masih memiliki pemilihan makanan kemasan yang kurang baik. Jika dilihat dari persentasenya, hasil post-test pemilihan makanan kemasan pada kelompok edukasi personal lebih baik daripada kelompok ceramah karena sebagian besar responden memiliki pemilihan makanan kemasan yang baik. Sedangkan pada kelompok ceramah hampir seluruh responden memiliki pemilihan makanan kemasan yang masih kurang baik. Jika dilihat pada tabel 3, skor pemilihan makanan kemasan pada kelompok edukasi personal mengalami peningkatan (80 poin), namun tidak terjadi peningkatan skor yang signifikan pada kelompok ceramah. Adapun pre-test dan posttest pemiihan makanan kemasan responden responden dapat dilihat pada Tabel 2 dan 3.

Tabel 2. Perbedaan Tingkat Pengetahuan dan Pemilihan Makanan Kemasan

\begin{tabular}{|c|c|c|c|c|c|c|c|}
\hline \multirow{4}{*}{ Variabel } & \multicolumn{6}{|c|}{ Kelompok } & \multirow{4}{*}{$p$-Value } \\
\hline & \multicolumn{3}{|c|}{ Edukasi personal } & \multicolumn{3}{|c|}{ Ceramah } & \\
\hline & Baik & Cukup & Kurang & Baik & Cukup & Kurang & \\
\hline & $n(\%)$ & $n(\%)$ & $n(\%)$ & $n(\%)$ & $n(\%)$ & $n(\%)$ & \\
\hline \multicolumn{8}{|c|}{ Tingkat Pengetahuan (kategori) } \\
\hline Sebelum & $0(0)$ & $8(36,4)$ & $14(63,6)$ & $0(0)$ & $6(27,3)$ & $16(72,7)$ & $0,517^{a}$ \\
\hline Sesudah & $17(77,3)$ & $5(22,7)$ & $0(0)$ & $11(50)$ & $5(45,5)$ & $1(4,5)$ & $0,038^{\mathrm{b} *}$ \\
\hline$p$-Value & & $0,000{ }^{c^{*}}$ & & & $0,000^{c^{*}}$ & & \\
\hline \multicolumn{8}{|c|}{ Pemilihan Makanan Kemasan (kategori) } \\
\hline Sebelum & $0(0)$ & $0(0)$ & $22(100)$ & $0(0)$ & $0(0)$ & $22(100)$ & $1,000^{b}$ \\
\hline Sesudah & $13(59,1)$ & $5(22,7)$ & $4(18,2)$ & $0(0)$ & $1(4,5)$ & $21(95,5)$ & $0,000^{b^{*}}$ \\
\hline$p$-Value & & $0,000^{c^{*}}$ & & & $0,317^{c}$ & & \\
\hline
\end{tabular}

Tabel 3. Perbedaan Skor Pengetahuan dan Pemilihan Makanan Kemasan

\begin{tabular}{|c|c|c|c|}
\hline \multirow{3}{*}{ Variabel } & \multicolumn{2}{|c|}{ Kelompok } & \multirow{3}{*}{$p$-Value } \\
\hline & Edukasi personal & Ceramah & \\
\hline & Median (Perc 25-Perc 75) & Median (Perc 25-Perc 75) & \\
\hline \multicolumn{4}{|c|}{ Pengetahuan (skor) } \\
\hline Sebelum & $58,8(52,9-70,6)$ & $58,8(47,1-64,7)$ & $0,489^{a}$ \\
\hline Sesudah & $91,2(80,9-100)$ & $79,4(69,1-94,1)$ & $0,021^{a *}$ \\
\hline$p$-Value & $0,000^{\mathrm{b}^{*}}$ & $0,000^{b^{*}}$ & \\
\hline \multicolumn{4}{|c|}{ Pemilihan Makanan Kemasan (skor) } \\
\hline Sebelum & $00,0(00,0-00,0)$ & $00,0(00,0-00,0)$ & $0,317^{\mathrm{a}}$ \\
\hline Sesudah & $80,0(60,0-100)$ & $00,0(00,0-20,0)$ & $0,000^{\mathrm{a} *}$ \\
\hline$p$-Value & $0,000^{b^{*}}$ & $0,161^{b^{*}}$ & \\
\hline
\end{tabular}

Keterangan: ${ }^{*}$ terdapat perbedaan signifikan dengan nilai $\mathrm{p}<0.05$; a : Uji Mann-Whitney; $\mathrm{b}$ : Uji Wilcoxon 
Hasil analisis pre-test post-test skor dan tingkat pengetahuan pada kedua kelompok menunjukkan bahwa terdapat perbedaan yang signifikan antara tingkat pengetahuan sebelum dan sesudah pemberian edukasi gizi pada kelompok edukasi personal $(p=0,000)$. Hal ini sejalan dengan hasil penelitian terkait edukasi demam berdarah dengue yang menyatakan bahwa metode pendidikan individual yang digunakan pada pendidikan kesehatan dapat memberikan efek nyata pada peningkatan pengetahuan keluarga ${ }^{23}$. Hasil penelitian juga menunjukkan bahwa terdapat perbedaan yang signifikan pada skor dan tingkat pengetahuan sebelum dan sesudah pemberian edukasi gizi pada kelompok edukasi ceramah $(p=0,000)$. Sejalan dengan hasil penelitian pada siswi SMA yang menyebutkan bahwa adanya peningkatan pengetahuan menjadi baik setelah diberi edukasi terkait dismenorea menggunakan metode ceramah ${ }^{24}$. Dari uraian tersebut dapat diketahui bahwa pada penelitian ini, metode edukasi personal dan metode ceramah dapat memberikan dampak pada peningkatan tingkat pengetahuan.

Untuk hasil analisis pre-test post-test skor dan kategori pemilihan makanan kemasan responden pada kedua kelompok menunjukkan bahwa pada kelompok edukasi personal terdapat perbedaan yang signifikan $(p=0,000)$ antara pre-test dan post-test pemilihan makanan kemasan setelah pemberian eduasi gizi. Sejalan dengan penelitian yang menyebutkan bahwa adanya strategi edukasi terkait makanan dan gizi seperti konseling dapat meningkatkan pemilihan makanan dan pola makan yang sehat pada remaja di San Paulo ${ }^{25}$. Sedangkan hasil penelitian pada kelompok ceramah menunjukkan bahwa tidak terdapat perbedaan yang signifikan pada skor $(p=0,161)$ dan kategori pemilihan makanan kemasan $(p=0,317)$ antara sebelum dan setelah pemberian edukasi gizi. Hal ini sejalan dengan hasil penelitian yang menyebutkan bahwa pemberian edukasi dengan metode ceramah tidak menujukkan perbedaan perilaku jajanan yang signifikan antara sebelum dan sesudahnya ${ }^{26}$. Adapun hasil analisis pre-test post-test tingkat pengetahuan dan kategori pemilihan makanan kemasan responden dapat dilihat pada Tabel 2 .
Pada penelitian ini, seluruh pertanyaan post-test tingkat pengetahuan sudah dijawab dengan benar oleh sebagian besar responden. Topik pertanyaan yang sudah dijawab dengan benar adalah terkait definisi label informasi nilai gizi, manfaat dan pentingnya membaca label informasi nilai gizi bagi orang obesitas, serta dampak kesehatan jika kelebihan intake energi. Namun, masih terdapat beberapa responden yang belum mencapai tahap memahami dan menginterpretasikan informasi yang didapatkan untuk menjawab soal posttest dengan benar. Topik pertanyaan yang masih dijawab salah oleh responden adalah terkait definisi takaran saji, alasan memilih makanan kemasan, dan interpretasi kandungan zat gizi yang tertera pada label Informasi Niai Gizi.

Sebagian besar kesalahan yang dilakukan responden adalah kurang memperhatikan informasi terkait jumlah sajian per kemasan, sehingga terdapat kesalahan interpretasi kandungan gizi yang dilakukan responden. Hal ini dimungkinkan karena sebagian besar responden belum pernah mendapatkan edukasi terkait cara membaca dan menginterpretasikan informasi pada label dengan benar sehingga tidak mudah untuk mengubah pemahaman dan kebiasaan responden dalam membaca label informasi nilai gizi tersebut.

Pada kuesioner pemilihan makanan kemasan, hasil pre-test menunjukkan bahwa hampir seluruh responden melakukan pemilihan makanan kemasan yang salah karena memilih produk dengan densitas energi yang lebih tinggi dan dengan alasan yang tidak tepat. Alasan yang paling sering adalah responden memilih karena mempertimbangkan kesukaan dari produk dan kandungan energinya saja. Hanya sedikit responden yang memilih produk dengan memperhatikan densitas energi dan jumlah sajian per kemasannya. Setelah diberi edukasi, hasil post-test pemilihan makanan kemasan pada kedua kelompok terjadi peningkatan.

Namun, pada kelompok ceramah sebagian besar pemilihan makanan kemasan responden masih dalam kategori kurang baik. Hal ini memungkinkan terjadi karena sebelumnya sebagian besar responden belum pernah mendapatkan informasi terkait cara 
memilih makanan kemasan melalui label informasi nilai gizi dan hasil tingkat pengetahuan pada kelompok ceramah sebagian besar masih tergolong kurang baik sehingga akan mempengaruhi dalam pemilihan yang dilakukan. Selain itu, kelemahan dari pemberian edukasi pada penelitian ini adalah hanya dilakukan sekali karena keterbatasan sumberdaya sehingga disarankan untuk peneliti selanjutnya agar dapat meningkatkan kualitas dan kuantitas dari proses edukasi yang diberikan.

Adanya peningkatan pengetahuan terkait cara yang benar dalam membaca label informasi nilai gizi ini sangat berperan penting dalam tindakan pemilihan makanan kemasan bagi orang dengan status gizi obesitas ${ }^{5,6}$. Sejalan dengan hasil penelitian yang menyatakan bahwa pemberian edukasi gizi pada remaja dengan status gizi berlebih dapat meningkatkan pengetahuan gizi yang dimiliki dan berdampak pada perubahan dalam pemilihan makanan yang sesuai dengan kebutuhan gizinya ${ }^{17}$.

Dengan menerapkan pembacaan label informasi nilai gizi ini dapat menjadi salah satu upaya preventif dan promotif dalam mengontrol asupan energi bagi orang dengan status gizi obesitas ${ }^{8}$. Faktor penyebab utama berasal dari lingkungan seperti perilaku dalam pemilihan makanan kemasan yang kurang baik, lebih memilih junk food dan minuman ringan/softdrink, terbiasa konsumsi jajan dan mengemil snack terutama golongan kripik dan makanan instan ${ }^{9,10}$. Dengan menerapkan pemilihan makanan kemasan berdasarkan informasi kandungan gizi pada label, diharapkan masyarakat terutama pada orang obesitas ini dapat lebih teliti dan pintar dalam memilah dan memilih makanan atau camilan yang baik untuk dikonsumsi.

\section{Analisis Perbedaan Tingkat Pengetahuan dan Pemilihan Makanan Kemasan Sebelum dan Sesudah Pemberian Edukasi Gizi antara Metode Edukasi Personal dan Ceramah}

Hasil analisis pre-test post-test antara kedua kelompok dapat dilihat pada Tabel 2 dan 3. Berdasarkan hasil penelitian didapatkan bahwa sebelum pemberian edukasi, skor pengetahuan $(p=0,489)$ dan tingkat pengetahuan responden $(p=0,517)$ antara kedua kelompok adalah homogen, yaitu sebagian besar tergolong kurang baik. Didukung dengan hasil penelitian yang menyatakan bahwa tingkat pegetahuan dipengaruhi oleh paparan informasi dan pengetahuan dari lingkungan ${ }^{27}$. Untuk pre-test pemilihan makanan kemasan, hasil penelitian didapatkan bahwa skor $(p=0,317)$ dan kategori pemilihan makanan kemasan $(p=1,000)$ seluruh responden pada kedua kelompok adalah homogen, yaitu tergolong kurang baik. Didukung dalam hasil penelitian yang menyatakan bahwa pemilihan makanan pada remaja di Yunani dipengaruhi oleh pengetahuan terkait makanan, diet, dan kepedulian terhadap berat badan ${ }^{28}$.

Hasil pre-test penelitian ini dimungkinkan terjadi karena sebagian besar responden belum pernah terpapar informasi terkait label informasi nilai gizi dan bagaimana cara memilih makanan kemasan berdasarkan label informasi nilai gizi tersebut. Adapun informasi yang pernah didapatkan oleh responden sebagian besar masih kurang jelas sehingga masih belum dapat meningkatkan pengetahuan dan pemahaman responden terkait cara membaca label informasi nilai gizi. Kesetaraan hasil pre-test pada kedua kelompok sebelum dilakukan perlakuan ini akan memberikan hasil yang akurat untuk menilai hasil dari metode edukasi yang diberikan.

Berdasarkan hasil penelitian pada tabel 2 dan 3, terdapat perbedaan yang signifikan pada skor pengetahuan $(p=0,021)$ dan tingkat pengetahuan $(p=0,038)$ antara kedua kelompok setelah diberi edukasi gizi terkait cara membaca label informasi nilai gizi. Untuk pemilihan makanan kemasan, didapatkan bahwa terdapat perbedaan yang signifikan pada skor dan kategori pemilihan makanan kemasan antara kedua kelompok setelah diberi edukasi gizi terkait cara membaca label informasi nilai gizi $(p=0,000)$. Dilihat dari hasil post-test pada pembahasan sebelumnya dapat disimpulkan bahwa tingkat pengetahuan dan pemilihan makanan kemasan pada kelompok edukasi personal lebih baik daripada kelompok edukasi dengan metode ceramah. Sejalan dengan hasil penelitian pada pasien asma di RSP dr. Ario Wirawan Salatiga yang menyatakan bahwa metode penyuluhan individual lebih efektif dalam meningkatkan 
pengetahuan responden terkait upaya pencegahan kekambuhan pasien dibandingkan dengan media leaflet ${ }^{29}$.

Didukung juga dengan hasil penelitian yang menyatakan bahwa terdapat perbedaan pengetahuan antara kelompok kontrol dan eksperimen setelah pemberian pendidikan kesehatan menggunakan metode pendidikan individual $^{23}$. Sejalan juga dengan hasil penelitian yang menyebutkan bahwa metode ceramah kurang efektif dalam meningkatkan sikap terkait kesehatan dan merokok jika dibandingkan metode diskusi ${ }^{30}$. Hasil penelitian menyatakan bahwa pendidikan gizi dengan metode ceramah melalui media booklet yang diberikan sudah dapat meningkatkan pengetahuan remaja putri terkait anemia, namun belum dapat mengubah zat gizi yang dikonsumsi ${ }^{31}$.

Sehingga dengan meningkatnya pengetahuan responden maka akan berpengaruh juga pada pemlihan makanan kemasan yang dilakukan, namun kurang efektif dengan metode ceramah. Pendidikan gizi akan mempengaruhi faktor-faktor yang berpengaruh pada pemilihan makanan sehingga membentuk pemilihan makanan dan kebiasaan makan yang sesuai ${ }^{32}$. Sejalan dengan hasil post-test tingkat pengetahuan responden yang juga mengalami peningkatan, pemilihan makanan kemasan pada kelompok edukasi personal lebih meningkat karena dimungkinkan sebagian besar responden sudah paham dan dapat menginterpretasikan pengetahuan yang didapat untuk memilih makanan kemasan pada post-test secara tepat agar dapat mengontrol asupan makannya. Hal ini dimungkinkan karena adanya perbedaan daya terima terhadap materi edukasi yang disampaikan meskipun dengan menggunakan media dan durasi edukasi yang sama.

Pada edukasi gizi yang diberikan dengan metode edukasi personal atau bimbingan dan konseling, terdapat kontak yang lebih intensif antara penerima informasi dan pemberi informasi yaitu dengan adanya komunikasi langsung dengan tatap muka ${ }^{11}$. Didukung juga dengan adanya proses pemberian edukasi lebih terfokus pada satu individu saja sehingga terdapat respon yang baik dari responden seperti memperhatikan secara sungguhsungguh dan berkonsentrasi selama membaca booklet dan mendengarkan penjelasan materi. Responden juga aktif saat diminta mereview kembali materi yang sudah disampaikan. Responden lebih leluasa dalam menerima informasi dan menanyakan hal-hal yang kurang dipahami tanpa mendapat pengaruh dari lingkungan, seperti adanya pengaruh teman satu kelompok yang heterogen pada kelompok metode ceramah. Metode edukasi ceramah adalah metode yang digunakan untuk menyampaikan penjelasan secara verbal pada berbagai kalangan dan biasanya terjadi komunikasi yang satu arah antara pemberi edukasi dan sejumlah sasaran ${ }^{11}$. Pada metode edukasi ceramah, lingkungan memiliki pengaruh yang lebih besar jika dibandingkan dengan metode edukasi personal. Kekerabatan dalam satu kelompok edukasi dimungkinkan dapat membuat responden cenderung pasif, terlalu aktif, kurang tertarik atau kurang fokus dengan edukasi yang diberikan ${ }^{33}$. Selain itu, jenis kelamin juga memungkinkan menjadi salah satu faktor yang mempengaruhi, dimana responden laki-laki cenderung lebih sulit untuk diam, kurang fokus dan kurang memperhatikan edukasi yang diberikan oleh peneliti ${ }^{34}$.

Pada penelitian ini, sebelum proses intervensi dilakukan, peneliti telah terlebih dahulu menjelaskan peraturan-peraturan selama edukasi berlangsung agar seluruh responden pada penelitian ini dapat aktif, fokus, tercipta suasana kondusif, dan meminimalisir pengaruh dari luar. Namun pada penelitian ini, sebagian besar responden pada kelompok ceramah cenderung lebih pasif dan memiliki konsentrasi yang lebih rendah selama proses edukasi jika dibandingkan dengan responden pada kelompok edukasi personal. Hal ini memungkinkan terjadi karena fokus dan kontak dari pemberi edukasi harus terbagi kepada seluruh peserta ceramah sehingga pemahaman dan daya terima informasi dari setiap responden tidak dapat dikontrol seluruhnya oleh pemberi edukasi. Namun responden tetap mencoba mendengarkan dengan baik selama penjelasan materi dari petugas sehingga responden pada kelompok ceramah ini juga mendapatkan informasi yang dapat mengubah tingkatan pengetahuan yang dimiliki meskipun tidak sebaik pada kelompok metode edukasi personal. Pada kelompok 
ceramah sebagian besar responden baru mencapai tahap tahu dan masih belum dapat memahami dan menginterpretasikannya dalam pemilihan makanan.

Kelebihan dari penelitian ini adalah belum ada penelitian terkait metode edukasi yang tepat untuk label informasi nilai gizi pada kalangan mahasiswa obesitas dan seluruh proses pelaksanaan penelitian diamati langsung oleh peneliti dan proses intervensi edukasi kepada responden dilaksanakan oleh peneliti sendiri tanpa bantuan enumerator, sehingga meminimalisir adanya bias dalam pemberian intervensi edukasi yang diberikan.

Namun, kelemahan dari penelitian ini adalah keterbatasan sumber daya seperti dana, waktu, dan tenaga sehingga untuk penelitian selanjutnya diharapkan dapat mengembangkan baik dari segi jumlah responden maupun intensitas intervensi yang diberikan. Selain itu, quasi experimen memiliki kelemahan pada validitas internalnya. Namun berbagai upaya telah dilakukan pada penelitian ini, diantaranya dengan memaksimalkan validitas isi dan konteks dari instrumen yang digunakan (kuesioner pre-test dan post-test) agar dapat benar-benar menggali informasi yang dibutuhkan sesuai dengan materi/topik dari penelitian serta sudah teruji validitas dan reliabilitasnya sehingga dapat benar-benar mengukur efek dari intervensi edukasi yang diberikan.

Observer/pengamat perilaku adalah peneliti sendiri dan sama sampai akhir penelitian sehingga dapat meminimalisir perbedaan hasil observasi karena adanya perubahan observer. Pada pelaksanaan penelitian ini tidak diperkenankan melakukan pengulangan pengukuran yang mempengaruhi peningkatan performa responden sehingga ancaman testing pada validitas internal dapat dihindari. Jarak antara pre-test dan post-test tidak terlalu lama ( 7 hari) ditujukan agar meminimalisir adanya pengaruh dari luar perlakuan. Selain itu, responden pada kedua kelompok intervensi telah diupayakan memiliki karakteristik yang sama dan telah teruji homogenitasnya sehinggan ancaman seleksi yang mencadi kelemahan peneitian quasi dapat diminimalisir. Untuk peneliti selanjutnya, penelitian dengan metode kualitatif memungkinan untuk dapat menggali informasi dan faktor-faktor yang berpengaruh lebih mendalam kepada responden.

\section{KESIMPULAN}

Pada penelitian ini, dapat disimpulkan bahwa terdapat perbedaan yang signifikan pada tingkat pengetahuan dan pemilihan makanan kemasan antara kelompok edukasi personal dan ceramah sesudah pemberian edukasi gizi terkait cara membaca label informasi nilai gizi. Namun, perbedaan tingkat pengetahuan pada metode ceramah tidak signifikan pada pemilihan makanan kemasan. Metode edukasi personal lebih efektif daripada metode ceramah untuk meningkatkan pengetahuan terkait cara membaca label informasi nilai gizi dan pemilihan makanan kemasan pada mahasiswa obesitas sehingga metode edukasi personal/konseling lebih disarankan untuk diterapkan dalam upaya preventif dan promotif kejadian obesitas pada kalangan mahasiswa.

\section{ACKNOWLEDGEMENT}

Penulis mengucapkan banyak terima kasih kepada seluruh dosen, karyawan, dan teman sejawat program studi S1 ilmu gizi Fakultas Kedokteran Universitas Brawijaya serta dosen pembimbing atas bantuan dan arahan selama pelaksanaan penelitian ini.

\section{REFERENSI}

1. Presiden Republik Indonesia. UndangUndang Republik Indonesia Nomor 18 Tahun 2012 Tentang Pangan. 1-83 (2012).

2. Menteri Kesehatan Republik Indonesia. Pedoman Gizi Seimbang. (2014).

3. Badan Perlindungan Konsumen Nasional (BPKN). Hasil Kajian Badan Perlindungan Konsumen Nasional (BPKN) di Bidang Pangan Terkait Perlindungan Konsumen Jakarta. (2007).

4. Mediani, N. V. Pengetahuan, Persepsi, Sikap, dan Perilaku Membaca Label Informasi Gizi pada Mahasiswa. [skripsi] Institut Pertanian Bogor (2014).

5. Wardhani, D. T. K. Hubungan Pengetahuan Diet dan Perilaku 
Membaca Informasi Nilai Gizi Produk Makanan Kemasan terhadap Kepatuhan Diet Pasien Penyakit Jantung Koroner (PJK) dengan Hipertensi Rawat Jalan Di RSUD Dr. Moewardi. [publikasi ilmiah] Universitas Negeri Surakarta. (2016).

6. Devi, V. C., Sartono, A. \& Isworo, J. T. Praktek Pemilihan Makanan Kemasan Berdasarkan Tingkat Pengetahuan Tentang Label Produk Makanan Kemasan, Jenis Kelamin, dan Usia Konsumen di Pasar Swalayan ADA Setiabudi Semarang. Gizi 2, 1-12 (2013).

7. Badan Penelitian dan Pengembangan Kesehatan. Riset Kesehatan Dasar (RISKESDAS) 2013. Laporan Nasional 2013 (2013).

8. Dinkes Kota Malang. Profil Kesehatan Kota Malang Tahun 2014. Dinas Kesehatan. (2014).

9. Kemenkes RI. Pedoman Pencegahan Dan Penanggulangan Kegemukan Dan Obesitas pada Anak Sekolah. Kementerian Kesehatan Republik Indonesia. (2012).

10. Novitasari, D. Hubungan Kejadian Binge Eating Dengan Indeks Massa Tubuh (IMT), Lingkar Pinggang, Dan Persen Lemak Tubuh Pada Mahasiswa Obesitas Di Kota Malang. [skripsi] Fakultas Kedokteran Universitas Brawijaya. (2016).

11. Notoatmojo, S. Ilmu Perilaku Kesehatan. Rineka Cipta. (2010).

12. Benih, A. Sosiologi Kesehatan. Nuha Medika. (2014).

13. Thomas, D., Donald, T., Hastjarjo, D. \& Quasi-, C. Ringkasan Cook, Thomas D \& Campbell, Donald T. (1979). QUASIEXPERIMENTATION: DESIGN \& ANALYSIS ISSUES FOR FIELD SETTINGS. Houghton Mifflin Company: Boston. Dicky. (2008).

14. Irhamna, V. Perbedaan Pengetahuan, Sikap, dan Tindakan antara Mahasiswa Jurusan Gizi dan Mahasiswa Jurusan Teknik Elektromedik Poltekkes Kemenkes Jakarta II dalam Membaca Label Pangan. Politeknik Kesehatan Kementerian Kesehatan Jakarta II Kementerian Kesehatan RI.\& (2014).

15. National Center for Chronic Disease Prevention and Health Promotion. Low-
Energy-Dense Foods and Weight Management: Cutting Calories While Controlling Hunger. Res. to Pract. Ser. 5, 1-7 (2011).

16. Haryana, N. R. Hubungan Tingkat Pengetahuan Tentang Label Informasi Gizi Terhadap Pemilihan Produk Makanan Kemasan pada Mahasiswa Gizi Fakultas Kedoktern Universitas Brawijaya. [skripsi] Fakultas Kedokteran Universitas Brawijaya. (2014).

17. World Cancer Research Fund. Energy Density: Finding the Balance for Cancer Prevention. Am. Inst. Cancer Res. 1-8 (2012).

18. Safitri, C. H., Wilujeng, C. S. \& Handayani, D. Perbedaan Metode Team Game Tournament Dan Ceramah Terhadap Peningkatan Pengetahuan Pemilihan Jajanan Sehat. Indones. J. Hum. Nutr. 1, 89-105 (2014).

19. Rahman, R. T. . Analisis Statistik Penelitian Kesehatan. In Media. (2015).

20. Dahlan, M. S. Statistik untuk Kedokteran dan Kesehatan. Salemba Medika. (2011).

21. Khory, N. Faktor - Faktor yang Berhubungan dengan Konsumsi Makanan Kemasan pada Mahasiswa Fakultas Kesehatan Universitas Dian Nuswantoro Kota Semarang Tahun 2016. [skripsi] Universitas Dian Nuswantoro. (2016).

22. IImi, A. R. Perilaku Pencarian Informasi Dengan Menggunakan Media Internet Pada Remaja Awal (Studi Deskriptif Perilaku Pencarian Informasi Dengan Menggunakan Media Internet Pada SMPN 32 Surabaya). J. Univ Airlangga 116 (2013).

23. Yusyaf, S. R. \& Dewi, Y. I. Efektifitas Pendidikan Kesehatan Menggunakan Metode Pendidikan Individual Terhadap Peningkatan Pengetahuan Keluarga Tentang Demam Berdarah Dengue. Laporan Penelitian 1, 1-6. (2012).

24. Rosyidah, I. \& Winarni. Efektifitas Ceramah dan Audio Visual dalam Peningkatan Pengetahuan Dismenorea pada Siswi SMA. Gaster XIV, 90-99 (2016).

25. Baldasso, J. G., Galante, A. P. \& De Piano Ganen, A. Impact of actions of food and 
nutrition education program in a population of adolescents. Rev. Nutr. 29, 65-75 (2016).

26. Maduretno, I. S., Setijowati, N. \& Wirawan, N. N. Niat dan Perilaku Pemiihan Jajanan Anak Sekolah yang Mendapat Pendidikan Gizi Metode Ceramah dan TGT. Indones. J. Hum. Nutr. 2, 23-37 (2015).

27. Triastuti, W. Analisis Perubahan Pengetahuan Terhadap Membaca Label Pangan Dalam Pencegahan Kegemukan Dan Obesitas Pada Ibu Rumah Tangga Di Kelurahan Mampang Depok Tahun 2011. [skripsi] Universitas Indonesia. (2012).

28. Bargiota, A., Pelekanou, M., Tsitouras, A. \& Koukoulis, G. N. Eating habits and factors affecting food choice of adolescents living in rural areas. Horm Behav. 12, 246-53 (2013).

29. Setiyarini, T. Efektivitas Pendidikan Kesehatan Menggunakan Media Leaflet dan Penyuluhan Individual terhadap Pengetahuan Pencegahan Kekambuhan Asma. Naskah Publikasi UMS,1-17. (2016).

30. Qiftiyah, M. Perbedaan Penyuluhan dengan Metode Ceramah dan Diskusi Terhadap Perilaku Merokok Di SMA Negeri 4 Tuban. [Skripsi] Stikes NU Tuban. (2012).

31. Silalahio, V., Aritonang, E. \& Ashar, T. Potensi Pendidikan Gizi Dalam Meningkatkan Asupan Gizi Pada Remaja Putri Yang Anemi Di Kota Medan. J. Kesehat. Masy. 11, 96-102 (2016).

32. Contento, I. R. Nutrition Education: Linking Theory, Research, and Practice 2nd Edition. Jones \& Barlett Publishers, LLD. (2011).

33. Nurmasyita, Widjanarko, B. \& Margawati, A. Pengaruh intervensi pendidikan gizi terhadap peningkatan pengetahuan gizi , perubahan asupan zat gizi dan indeks massa tubuh remaja kelebihan berat badan. J. Gizi Indones. Vol.4, No., 38-47 (2015).

34. Harton, N. P., Wilujeng, C. S. \& Andarini, $S$. Indonesian Journal of Human Nutrition. Pendidikan Gizi tentang Pengetahuan Pemilihan Jajajan Sehat antara Metode Ceramah dan Metode Komik. Indones. J. Hum. Nutr 1, 135-148 (2015). 